\title{
The Development of Post-Modern Islamic Boarding Schools (Case Study at IHAQI Creative Pesantren in Bandung)
}

\author{
Nurti Budiyanti' ${ }^{1}$, Nurwadjah Ahmad ${ }^{2}$, Andewi Suhartini' ${ }^{2}$, Muhamad Parhan ${ }^{1}$ \\ ${ }^{1}$ Universitas Pendidikan Indonesia \\ ${ }^{2}$ Universitas Islam Negeri (UIN) Sunan Gunung Djati \\ *Corresponding email: nurtibudiyanti@upi.edu
}

Naskah diterima: 23 Maret 2021 | Disetujui:09 April 2021 | Diterbitkan: 10 Mei 2021

\begin{abstract}
Religious education is fundamental to be improved, as moral degradation continues to take root around the world. One of the efforts to maintain religious teachings' value is through the education system, among others through boarding school education. The presence of boarding schools in the middle of society is an educational institution and a religious and religious broadcasting institution. This research uses a qualitative approach with case study methods at IHAQI Boarding Creative Boarding School in Bandung. The study results illustrate that historically pesantren continues to change; in the 21 st century, pesantren developed Pondok to "Boarding School," one of them in IHAQI Creative Boarding School. It shows the birth of the modern post generation as a form of modern boarding school progress in the Industrial Revolution 4.0 era. In addition to displaying religious knowledge, modern post pesantren that exists in the 21 st century also displays various skills in various fields of science. Pesantren has a unique and creative Boarding School system in developing various disciplines and skills needed by the community. This pesantren became a post-modern boarding school that excelled in printing a generation of digital-based Islam.
\end{abstract}

Keywords: Pesantren; Development; Post-Modern

\begin{abstract}
Abstrak
Pendidikan agama menjadi hal yang fundamental yang harus dibenahi, mengingat degradasi moral terus mengakar di seluruh penjuru dunia. Salah satu ikhtiar untuk menguatkan nilai ajaran agama adalah melalui sistem pendidikan, antara lain melalui pendidikan pondok pesantren. Keberadaan pesantren di masyarakat tidak hanya sebagai lembaga yang berorientasi pada pendidikan keagamaan, tetapi juga sebagai lembaga yang terlibat aktif dalam wilayah sosial kemasyarakatan. Penelitian ini menggunakan pendekatan kualitatif dengan metode studi kasus di Pesantren Kreatif IHAQI Boarding School Bandung. Hasil penelitian menggambarkan bahwa secara historis pesantren terus mengalami perubahan, pada abad 21 ini pesantren berkembang menggunakan kata pondok menjadi "Boarding School", salah satunya di Pesantren Kreatif IHAQI. Hal ini menunjukan lahirnya generasi post modern sebagai bentuk kemajuan pesantren modern di masa perkembangan zaman revolusi industri 4.0, selain menampilkan pengetahuan agama, pesantren post modern yang ada di abad 21 ini juga menunjukkan berbagai keterampilannya di berbagai bidang ilmu. Pesantren ini memiliki sistem Boarding School yang unik dan kreatif dalam mengembangkan berbagai disiplin keilmuan dan keterampilan yang dibutuhkan masyarakat. Pesantren ini menjadi pesantren postmodern yang unggul dalam mencetak generasi muda muslim berbasis digital.
\end{abstract}

Kata Kunci: Perkembangan; Pesantren; Post-Modern 


\section{Introduction}

The implementation of Islamic teachings in daily life is well manifested and sustainable if religious values are structured and maintained in personal and social life to transform attitudes and values (Parhan \& Sutedja, 2019). The Word of Allah in Qs. Al-Tahrim verse 6 warns Muslims, especially parents, always to look after, guide, nurture and care for the family well not to disobey Allah SWT. in all aspects of life. One of the efforts to maintain the value of religious teachings and family life is through the education system, including through Islamic boarding school education (Alwi, 2016). As one of the countries whose population is predominantly Muslim, Indonesia has a distinctive and unique education system called pesantren (Suharto, 2011).

It is said to be unique because the pesantren model of education is only proliferating in Indonesia (Suhardi et al., 2012). In addition, Islamic boarding school education has unique characteristics that are not fully shared by schools in general, such as kyai, santri, Pondok, Kitab Kuning, and a mosque (Makmun, 2016). Apart from these peculiarities and uniqueness, it turns out that pesantren are also genuine Islamic education products from Indonesia. Some even say that the pesantren is the "father" of Islamic education in Indonesia (Mahdi, 2005). This pesantren education can lead to the achievement of National Education goals in Indonesia, so that religious values are structured and maintained in personal and community life.

The existence of Islamic boarding schools in Indonesia, in its development, dramatically affects the surrounding community, especially in terms of education. From the beginning, the pesantren was prepared to educate and spread Islamic teachings to the community through recitation, both with traditional and modern systems (Nihwan, 2017). Pesantren, in general, have similarities between one pesantren and another, namely the existence of ideological similarities and having the same references to the same teaching methods, thus making the pesantren have significant strength and can be taken into account by anyone. Among the strengths possessed by the pesantren is that the boarding school grows and is recognized by the surrounding community with the boarding system. Santri receives religious education through the recitation system or madrasah, which is entirely under the leadership of a Kiai, with charismatic and independent characteristics in all respects. The development of Islamic boarding school education manifests the community's need for an alternative education system (Alwi, 2016). We must know its development in depth so that practitioners of Islamic religious education understand that Islamic boarding schools have an extraordinary role and progress in Indonesia's success (Mahdi, 2005).

Based on the description above, the author feels it is essential to discuss pesantren's development, especially the 21 st-century post-modern pesantren. Knowing its historical journey will be easy to describe the extent of the progress, role, or contribution that Islamic boarding schools have given to Indonesian national education. One of the pesantren educational institutions that belong to the post-modern 21st century is the IHAQI Boarding School Bandung Creative Pesantren. The concept of the boarding school of this pesantren has a different nuance from other pesantren with efforts to align the concepts of various education components in following the developments of the era of industrial revolution 4.0. 


\section{Method}

This study aims to obtain an overview of the development of post-modern 21 st century pesantren. This study uses a qualitative approach with a case study method. In this research, data was traced to the history of the development of Islamic boarding schools to the post-modern period of the 21 st century, which became the case study's object focusing on the IHAQI Boarding School Bandung Creative Pesantren. Case study research is a research strategy, an empirical study that investigates a phenomenon in a real-life setting. This strategy can include qualitative evidence that relies on various sources and previous developments of theoretical propositions. Researchers collect, identify, analyze, and synthesize data to interpret the development of 21 st century post-modern pesantren at IHAQI Creative Islamic Boarding School.

\section{Results and Discussion}

\section{A. The Essence of Islamic Boarding Schools}

Pesantren is the oldest educational institution in Indonesia. The terms pesantren and pondok are two words that cannot be separated because every time discussing pesantren means discussing the concept of pondok in them. Thus, before explaining the meaning of pesantren, it means that it is necessary to explain the meaning of the word pondok first. Etymologically, the term pondok comes from Arabic, funduq, a lodging house, bedroom, dormitory, or simple guesthouse (Herman, 2013). In terms of terminology, the word pondok is often understood as a simple shelter for students or santri who are far from their place of origin (Dhofier 1995, 18). Meanwhile, according to Sugarda Poerbawakatja's opinion, Pondok is a place to stay for young people who follow Islamic religious lessons. The cottage's essence and reality are simplicity and a temporary place to live for knowledge claimants (Poerbakawatja 1982, 287).

The term pesantren comes from the word santri. Some say that the word santri comes from Tamil or Indian, shastri which means the teacher of the Koran or people who understand (scholars) books in Hinduism. On the other hand, some say that pesantren comes from a derivative of the word shastra, which means sacred books, religious books, or books about science (Dhofier 1995, 18). Another opinion says that pesantren comes from combining two words in the Sankrit language, namely sant, good human being, and tra which means helping (Arif, 2016). That way pesantren is a place for good human education (Hamid 1983, 328). In terminology, pesantren is an Islamic educational institution with a boarding or boarding system, where the kyai is the central figure, the mosque is the center for the animating activities, and the santri follows the teaching of Islam under the guidance of the kyai as the main activity (Wiryosukarto 1996, 51). Mastuhu expressed a similar definition, pesantren is a traditional Islamic educational institution that studies, understands, appreciates and practices Islamic teachings by emphasizing the moral aspects of religion as guidelines for daily behavior (Mastuhu 1988, 6).

The difference in understanding the pesantren above is due to the different interests and points of view used. However, if a thread is drawn, pesantren can be interpreted as a simple educational institution that teaches and internalizes Islamic teachings in daily life so that students (santri) become good people according to religious standards and are accepted by the wider community (Busahdiar, 2016). Meanwhile, the Islamic boarding school is an Islamic educational institution that teaches and 
internalizes Islamic teachings to students in a simple cottage environment to have religious abilities and noble character accepted by the community (Mahdi, 2005).

Indonesia is famous for its variety of ethnicities and cultures and its variety of languages. This language diversity can be seen in the mention of pesantren. Aceh calls pesantren the dayah or rangkang, Minangkabau calls surau and Madura calls pesantren. Meanwhile, in Java, they call pesantren the name pondok pesantren (Azra 2000, 17). The Islamic boarding school's objectives are: (1) To produce scholars who master religion science. (2) Educating Muslims who can implement religious law. (3) Educating objects to have basic skills relevant to the formation of a religious community. Meanwhile, the specific goal is to prepare students to become pious people in the religious knowledge taught by the kyai concerned and practice it in society (Zulhimma 2013, 168). Thus, Islamic boarding school education aims to produce santri who are tafaquh fid deen (understand religion) and develop intellectual, emotional and spiritual potential in everyday life (Shofiyyah, Ali, and Sastraatmadja, 2019).

A pesantren is a traditional Islamic education hostel where students live and study under one (or more) teacher known as "kiai". The students' dormitory is located in the pesantren complex where the kiai resides, which also provides a mosque for worship, a room for study, and other religious activities (Syafe'i, 2017). Apart from dormitories, mosques are an inseparable element from pesantren because they are considered the most appropriate places to educate students, especially in the practice of the five daily prayers, sermons, and Friday prayers, and teaching classical Islamic books. Another element of the pesantren is Kalsik Islamic books' teaching, especially the writings of scholars who adhere to the syafi'iyyah understanding, which is the only formal teaching within the pesantren environment (Baharuddin, 2014). The primary purpose of this teaching is to educate prospective scholars. The entire classical books taught can be classified into eight groups: (1) Nahwu-Sharaf (syntax-morphology); (2) Fiqh; (3) Ushul Fiqih; (4) Hadith; (5) Interpretation; (6) Tauhid; (7) Sufism and Ethics, (8) Other branches such as Tarikh and Balaghah. These books range from concise texts to texts consisting of thick volumes regarding hadith, tafsie, fqih, ushul fiqih, and tasawuf. All of these can also be classified into three groups, namely: (1) the basic books; (2) books of intermediate behavior; (3) significant books (Makmun, 2016).

In general, there are several mechanisms for pondok education and teaching systems, namely: (1) Using a traditional system that has complete freedom compared to modern schools so that there is a two-way relationship between santri and kyai. (2) Life in pesantren shows a democratic spirit because they practically work together to solve their non-curricular problems. (3) The Islamic boarding school system prioritizes simplicity, idealism, brotherhood, instilling self-confidence and courage in life. The methods commonly used in pesantren education are: (1) wetonan, a learning method in which the students follow the lesson by sitting around the kyai who explains the lesson. The students listened to their respective books and took notes if necessary. (2) the sorogan method is when students face the kyai by bringing the book they are studying. (3) The memorization method, which is a method in which samntri memorizes specific texts or sentences from the books they are studying (Zulhimma, 2013). Thus, these various methods must always be inherited for use in various religious education institutions based on pesantren.

Concerning human resources development (human resources), pesantren are expected to produce Muslim intellectuals (1). act by the provisions mandated by the Qur'an and al hadith to always position himself as a choeruum that can be an example in the community around him; (2). Fear of 76 
Allah SWT and not afraid of His creation; (3). Want to create prosperity and peace on earth; (4). Fear of spreading slander, daring to uphold truth and justice; (5). In doing anything, it is only to seek the pleasure of Allah SWT because they are fully aware of eternal happiness in the hereafter; (6). The characteristics of siddîq, amânah, tablîqh, fathânah, and always tawâdlu and tafakkur. (7). Have a high curiosity so that they can find new things that are useful for humans. These expectations, the primary key lies in educators' hands, who must have a strong character, be patient, istiqamah, assertive, attentive, fair and master the material to be conveyed (Siregar, 2018). So that the role of Islamic boarding schools in building Indonesian society is huge (Hidayat, Rizal, and Fahrudin, 2018). Therefore, modernizing the people and nation of Indonesia will be faster if Islamic boarding schools spearhead it. For this reason, Islamic boarding schools need to adjust their education and teaching patterns as well as the lives of their students so that Islamic boarding schools can become independent community institutions but remain on the foundation of the word of Allah SWT and the hadith of the Prophet Muhammad (Ismail, 2013).

\section{B. Development of Islamic Boarding School (Pesantren) in Indonesia}

Pesantren is a traditional form of education in Indonesia whose roots go back centuries before Indonesia's independence and before the Islamic empire (Mulkhan 2002, 80). Islam entered Indonesia in the 7th century AD. In historical records, the boarding school establishment began with a kiyai who lived (resided) in one place. Then came the students who wanted to learn from him and outside. Also, live in that place.

Meanwhile, living and education costs are provided jointly by the santri with the surrounding community's support. Therefore, it allows pesantren life to run stably without external economic turmoil (Ali 1995, 149). Furthermore, Islamic boarding schools have been known in Indonesia since the Walisongo era. Therefore, Islamic boarding schools are where the interaction between teachers and students, kyai and students, takes relatively high intensity to transfer Islamic knowledge and experience (Ismail 2002, 25).

The Ampel Islamic Boarding School, which Shaykh Maulana Malik Ibrahim founded, was the forerunner to establishing Islamic boarding schools because students felt obliged to practice their knowledge in their respective regions (Hasan, 2015). So the boarding schools were founded by following what they got at the Ampel Islamic Boarding School (Kamal 2018). The Ampel Denta Islamic boarding school became the guardians known as the wali songo or nine guardians. History records that from the Giri pesantren, students from Minang, Datuk ri Bandang, brought Islamic civilization to Makassar and other eastern parts of Indonesia, and then gave birth to Syekh Yusuf, the great scholar and figure of the nation's movement. Starting from Makassar, Banten, Sri Lanka to South Africa. So that in the early days of the development of Islam in the archipelago, the attention of the Islamic kingdom government to the development of Islamic education was quite significant. However, during the VOC and the Dutch East Indies government this condition changed. Obedient Islamic society seemed to be exiled. The ulama were kept away from society because they were considered to have the potential for "riots". It can be seen from the policy of the colonial government towards pilgrims. The government complicates Nusantara pilgrims' departure with various policies and tries to prevent them from returning to their homeland. In the end, Islamic boarding schools as educational institutions tend to move away from government influences (Herman, 2013). 
In the early stages of the formation of pesantren, mosques generally became educational centers for the community. It is in the mosque that learning activities are carried out. In subsequent developments, the pesantren was equipped with a boarding school or a residence for the students. The construction of pesantren facilities was led by Kyai, with the help of the surrounding community. In the past, the simplicity of the pesantren was apparent, both in terms of physical buildings, methods, study materials and other learning tools. It was based on the prevailing social and economic conditions at that time. What characterizes this institution is the sincerity of the students and the Kyai (Muhakamurrohman, 1970). In line with the increasingly rapid development of Islamic boarding schools and the flood of Arabic-language religious books, the learning model used in general is to take the form of halaqah as was the case in Bashra and Baghdad (Simuh 2003, 66).

After Indonesia's independence, pesantren contributed many important figures in the Indonesian government; namely Mukti Ali, who previously served as Minister of Religion. More importantly, M Natsir and the election of Abdurrahman Wahid (Gus Dur) as the fourth Indonesian President were also represents figures emerging from the pesantren circles. The resilience displayed by pesantren in facing the pace of development of the times shows that as an educational institution, pesantren can dialogue with its era, which in turn can raise hopes for the general public that pesantren can be used as alternative educational institutions at present and in the future of the nation. (Mujab, 2018). Then developed the modernization of Islamic education institutions in Indonesia, which can be seen from the form, system, and method of the pesantren, which has two periodizations; First, Ampel (salaf), reflecting simplicity comprehensively. Second, the Gontor Period, which reflects modernity in systems, methods and physical structures. Some of the reforms in the pesantren education system carried out by Gontor can be concluded on several things. Among them are: no madhab, the application of organization, the leadership system of the Kyai who does not recognize the inheritance and descent system, includes general material and English, does not recognize regional languages, the use of Arabic and English as the language of instruction and conversation, sports with all its branches. Therefore, Gontor has four principles, namely: being of high character, being healthy, free-thinking and knowledgeable (Herman, 2013).

The pesantren has three different styles through this long journey, namely traditional, modern and salafi ones. In Ponorogo Regency, Islamic boarding schools with traditional styles include the Darul Huda and Hudatul Muna Islamic Boarding Schools. In contrast, the modern ones include the Gontor Modern Islamic Boarding School, the Wali Songo Islamic Boarding School, and the Al-Iman Islamic Boarding School. The system adopted by the pesantren influences the characters it forms. Therefore, a pesantren alumnus has a different attitude and character from other pesantren alumni because he is influenced and shaped by the pesantren's style where he studies (Sulaiman, 2016). Meanwhile, in the Minister of Religion Regulation No. 3/1979 concerning Assistance to Islamic Boarding Schools, the Islamic boarding schools are categorized into: (a) Type A Islamic boarding schools, namely Islamic boarding schools which are entirely implemented traditionally; (b) Pondok Pesantren type B, namely Islamic boarding schools which teach classically (madrasah); (c) Pondok Pesantren type C, namely a boarding school that is only a boarding school, while the students study outside; (d) Pondok pesantren type D, namely the Islamic boarding school (Islamic boarding school), which operates a boarding school system as well as a school or madrasah system (Makmun 2016, 214). 
According to Ridwan Nasir, the types of pesantren can be classified into five, namely: (a) Salaf / Classical Islamic Boarding Schools, namely Islamic boarding schools in which there is a salaf education system (weton and sorogan) and a classical system (madrasah salaf); (b) Semi-developed Islamic boarding schools, namely Islamic boarding schools in which there is a salaf education system (weton and sorogan) and a private classical system (madrasah) with a 90\% and 10\% general curriculum; (c) Developing Islamic Boarding Schools, namely Islamic boarding schools such as semideveloped ones, but they are more varied in the field of curriculum, namely $70 \%$ religion and $30 \%$ general. There was also a three ministerial SKB madrasah with the addition of madrasah diniyah; (d) Khalaf / Modern Islamic Boarding School, which is like the form of a developing Islamic boarding school. It is just that the institutions in it are complete, including a public school system with the addition of diniyah (the practice of reading salaf books), universities (both public and religious). It has a cooperative and is also equipped with takhassus (Arabic and English); (e) Ideal Islamic Boarding School, namely as a modern Islamic boarding school, only the existing educational institutions are complete. In particular, in the fields of skills that include agriculture, engineering, fishery, and banking, they pay attention to their quality by not shifting the unique characteristics of the pesantren that are still relevant to community needs / the times (Makmun, 2016).

Based on the description above, the authors classify the development of the pesantren into the following diagram:

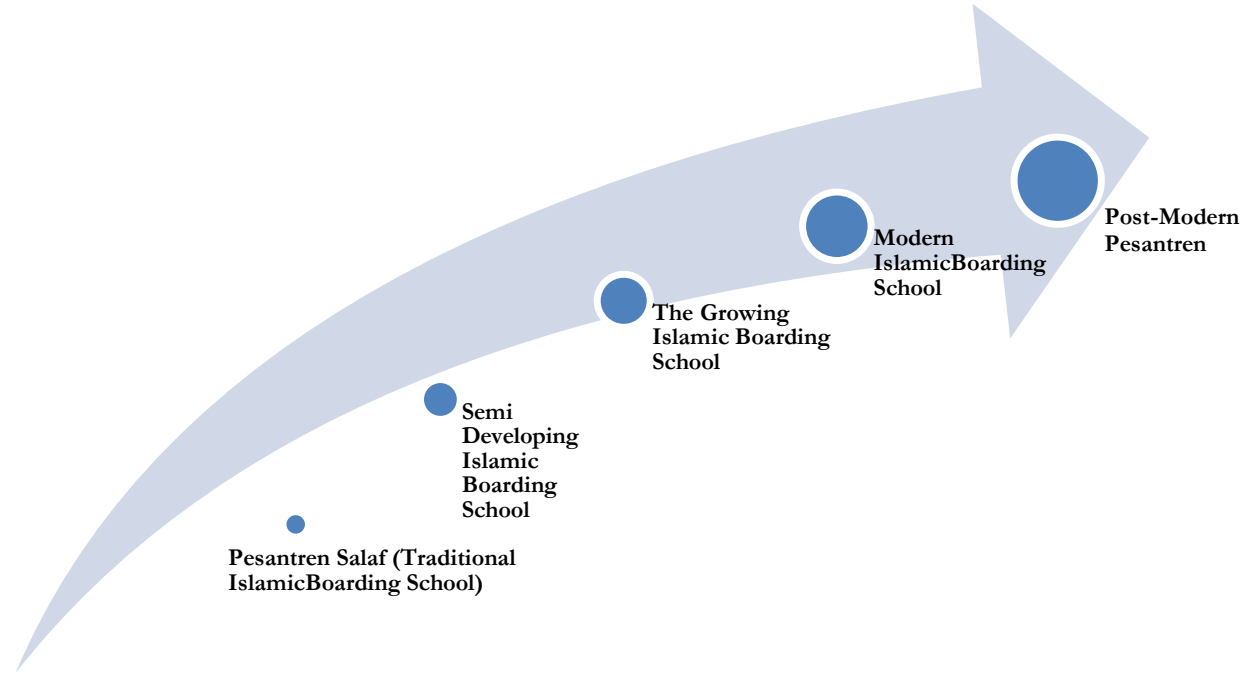

Figure 1. Pesantren Development Diagram

Thus, post-modern Islamic boarding schools are present as progress for modern Islamic boarding schools during the 4.0 industrial revolution era. Apart from displaying religious knowledge, post-modern Islamic boarding schools in the 21 st century also display various skills in various fields of science. Often, boarding schools in the 21st century use the term Boarding School, as we have found in Indonesia, especially in Bandung. A boarding school uses a unique and creative Boarding School system to develop the various scientific disciplines and skills needed.

The development of pesantren has had very significant changes from time to time, especially since the world is now responding to the acceleration of the industrial revolution 4.0, which has increasingly rapid technological sophistication (Lase, 2019). As a result, the pesantren's development has shifted the current stage to the post-modern stage in the 21 st century. One of the pesantren educational institutions with a post-modern concept is the IHAQI Boarding School Bandung Creative 
Pesantren. Post-modern pesantren is an Islamic boarding school that combines various modern technologies in the learning process and develops various scientific disciplines and skills needed without eliminating Islamic values.

\section{IHAQI as Post-Modern Islamic Boarding School}

The development of pesantren has had very significant changes from time to time, especially since the world is now responding to the acceleration of the industrial revolution 4.0, which has increasingly rapid technological sophistication (Lase, 2019). As a result, the development of pesantren shifted from the current stage to the post-modern stage in the 21 st century. One of the pesantren educational institutions that have a post-modern concept is the IHAQI Creative Pesantren. Post-modern pesantren is an Islamic boarding school that combines various modern technologies in the learning process and develops various scientific disciplines and skills needed without eliminating Islamic values.

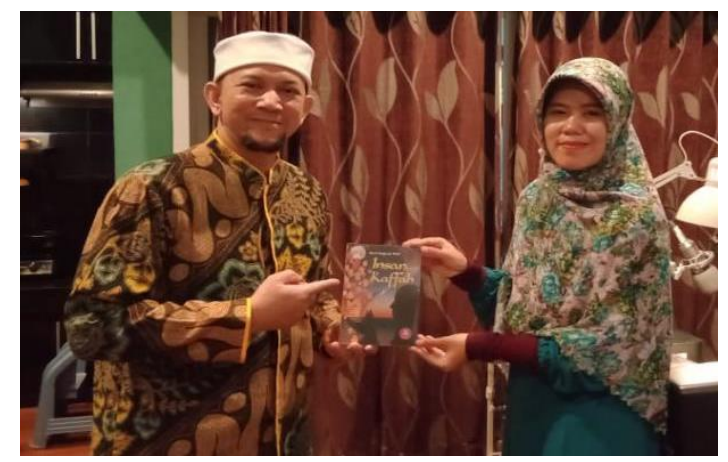

Figure 2. Owner of the IHAQI Creative Islamic Boarding School Bandung

The picture above shows the ulama figure who founded the post-modern pesantren named Ustadz Erick Yusuf. This pesantren was founded in 2017. Starting from the story of Ustadz Erick Yusuf, who admitted that he had difficulty finding a school for his child, his intention emerged to establish a school for himself according to his vision. Ustadz Erick wants a comprehensive-holistic educational institution thick with Islamic nuances and literacy with technology and creativity. From this idea, the IHAQI Boarding School Creative Pesantren was born. Ustadz Erick, who initiated this pesantren's establishment, really matured the concept of education to be built. It is evident from the students who are all Master graduates. These professional teachers also have high competence and qualifications in the field of education.

IHAQI Creative Islamic Boarding School is geographically located in the City of Bandung, coinciding on Jalan Bukit Raya Atas No. 575 Rt 02 Rw 010 Punclut Ciumbeleuit Cidadap Bandung. This pesantren educational institution's existence is in a strategic area, on the border between Bandung City and Bandung Regency. With a land area of 8000 M2, status for use, and a building area of 2000 M2. This pesantren already has a foundation deed and legal permits to carry out the learning process. The number of students so far has reached 50 students, in various levels of graduation and class. This pesantren is a post-modern pesantren that excels in creating a digital-based Islamic generation. The Boarding School system is not something new in the context of education in Indonesia. However, educational institutions in Indonesia have presented boarding school education that adopts the "Pondok Pesantren," whose educational pattern is more comprehensive-holistic. Therefore, it is more 
likely to create an ideal educational environment to produce people who will revolutionize the movement of life. Social, political, economic, and religious.

This pesantren has a motto: "dengan ilmu dan akhlak sukses dunia akhirat" (with the knowledge and morals of success in the hereafter). With a vision: "agamis, universal dan kreatif" (religious, universal, and creative). Religious in the sense that ideas, thoughts, actions, and behavioral activities must be tied to religious values, which undoubtedly bring goodness to the world. Then universal is where the entire academic community from teachers, clerics, staff employees, students, and guardians must have universal insight. Because with it, we can relate well to exchanging benefits or positive interconnections with humans, animals, and nature, and create value is one of the characteristics of the Prophet Muhammad, namely fathonah. Creative values can be interpreted as being intelligent and full of ideas and always getting solutions to the challenges that come your way. The IHAQI Boarding School, Creative Pesantren mission, is described as follows: (1) Cultivating and increasing faith and piety. (2) Carry out worship properly following the demands of the Prophet Muhammad. (3) Applying religious values in everyday life. (4) Mastering various disciplines, both religious and general. (5) Making religion and knowledge the basis of life. (5) Fostering creativity in life. (6) Upholding and applying moral values. (7) Fostering independence in life. (8) Increasing skill potential.

IHAQI Creative Islamic Boarding School wishes to present the concept of Islamic education that is religious and following the times. The concept applied in the IHAQI Creative Islamic Boarding School is a stepping stone, namely, learning gradually so that students do not need to be afraid or insecure about missing the subject matter. IHAQI Creative Pesantren has a transitional system that is not just a matter of setting sleeping hours, eating, and using gadgets. However, a system that seeks to make students independent to be wiser in managing their daily activities schedule. The educational process prioritized is the transfer of knowledge and the transfer of character by reliable educators who are postgraduate (S2). Mastery of language is absolute to be learned; students are directed to master three languages: Arabic, English,, and Indonesian. So, the students who graduate from the IHAQI Creative Islamic Boarding School are expected to preach in a beautiful, modern way that is well packaged and insightful.

The students attend regular education from morning to afternoon at school and then continue with religious education at night. During 24 hours, students are under the education and supervision of the supervisors. A boarding school is an educational institution where students study and live and live together with the institution. Apart from general and religious learning, there is also learning about digital media such as TV, radio, and journalism programs. The IHAQI creative pesantren also collaborates with several media in Indonesia, such as Republika and NET.TV so that students who have the desire or skills in the media field can be facilitated and learn directly from the source. The strength of the IHAQI Creative Pesantern with other Islamic boarding schools is a guaranteed security system for 24 hours. In addition to a security guard, CCTV in each corner of the pesantren room is always ready to monitor the students' movements. Apart from CCTV, there is also a separation of rooms between Ikhwan and older students, with each student having one mattress on the side. Dormitory so that the atmosphere of the student's dormitory room is more comfortable and pleasant. The iHAQi Creative Pesantren can accommodate up to 20 students. Finally, once a week on weekends, the students can be brought home by their parents to have time with their parents still.

Based on the description above, the IHAQI Boarding School Creative Islamic Boarding School is a 21 st-century post-modern Islamic boarding school that seeks to provide educational services 
according to the needs of the times. In industrial revolution 4.0-presenting various disciplines and various kinds of skills to give a creative impression in fostering the students' interest and talents at the pesantren. This effort can encourage the birth of the spirit of the younger generation in realizing Islamic values universally.

\section{Conclusion}

Islamic boarding schools are Islamic educational institutions that teach and internalize Islamic teachings to students in a simple cottage environment to have religious abilities and noble morals that society can accept. The Islamic boarding school's objectives are: (1) To produce scholars who master religion science. (2) Educating Muslims who can implement religious law. (3) Educating objects to have basic skills relevant to the formation of a religious community. Islamic boarding schools have a massive role in building Indonesian society. For this reason, Islamic boarding schools need to adapt their education and teaching patterns to keep up with the times, but not to erode existing Islamic values. In the 21st century, Islamic boarding schools have switched to using the word "Boarding School." It shows the post-modern generation's birth as a form of progress for modern Islamic boarding schools in the development era of the industrial revolution 4.0. Apart from displaying religious knowledge, post-modern Islamic boarding schools in the 21st century also display various skills in various fields of science. One of the pesantren educational institutions that use a unique and creative Boarding School system in developing various scientific disciplines and skills needed by the community is the IHAQI Creative Islamic Boarding School. Post-modern pesantren is an Islamic boarding school that combines various modern technologies in the learning process and develops various scientific disciplines and skills needed without eliminating Islamic values. This pesantren is a post-modern pesantren that excels in creating a digital-based Islamic generation. A more comprehensive-holistic education pattern makes it more likely to create an ideal educational environment to produce people who will revolutionize social, political, economic, and religious life movements.

\section{References}

Adnan Mahdi. 2005. "Sejarah Dan Peran Pesantren Dalam Pendidikan Di Indonesia." Islamic Review: Jurnal Riset dan Kajian Keislaman 2(1): 1-20. http://journal.ipmafa.ac.id/index.php/islamicreview/article/view/29.

Ali, Muhamad Daud. 1995. Lembaga-Lembaga Islam di Indonesia. Jakarta: PT Raja Grafindo Persada.

Arif, Mohammad. 2016. "Perkembangan Pesantren Di Era Teknologi." Jurnal Pendidikan Islam 28(2): 307.

Azra, Azyumardi. 2000. Islam Substantif Agar Umat Tidak Menjadi Buih. Bandung: Mizan.

B. Marjani Alwi. 2016. "Pondok Pesantren: Ciri Khas, Perkembangan, Dan Sistem Pendidikannya." Lentera Pendidikan : Jurnal Ilmu Tarbiyah dan Keguruan 16(2): 205-19. 
Baharuddin, Ismail. 2014. "Tumbuh Dan Berkembangnya Pesantren Di Indonesia." Forum Pedagogik Edisi Khus(Juli-Desember): 111-24.

Busahdiar. 2016. "Dinamika Pendidikan Di Pesantren." Misykat al-Anwar Jurnal Kajian Islam dan Masyarakat 27(2): 1-12. https://jurnal.umj.ac.id/index.php/MaA16/article/view/3827.

Dhofier, Zamakhsyari. 1995. Tradisi Pesantren. Jakarta: LP35.

Hamid, Abu. 1983. Sistem Pendidikan Madrasah dan Pesantren di Sulawesi Selatan. Jakarta: Rajawali Press.

Herman. 2013. “Sejarah Pesantren Di Indonesia.” Jurnal Al-Ta'dib 6(2): 145-58.

Hidayat, Tatang, Ahmad Syamsu Rizal, and Fahrudin Fahrudin. 2018. "Peran Pondok Pesantren Sebagai Lembaga Pendidikan Islam Di Indonesia." Ta'dib: Jurnal Pendidikan Islam.

Ismail, Fatah. 2002. Dinamika Pesantren dan Madrasah. Yogyakarta: Pustaka Pelajar.

Kamal, Faisal. 2018. "Transformasi Pendidikan Pesantren Sebagai Lembaga Pendidikan Islam Abad 21." Jurnal Paramurobi 17-30. https://www.academia.edu/37976966/TRANSFORMASI_PENDIDIKAN_PESANTREN_SE BAGAI_LEMBAGA_PENDIDIKAN_ISLAM_ABAD_21?email_work_card=title.

Lase, Delipiter. 2019. "Pendidikan Di Era Revolusi Industri 4.0." SUNDERMANN: Jurnal Ilmiah Teologi, Pendidikan, Sains, Humaniora dan Kebudayaan.

Makmun, H.A Rodli. 2016. "PEMBENTUKAN KARAKTER BERBASIS PENDIDIKAN PESANTREN: Studi Di Pondok Pesantren Tradisional Dan Modern Di Kabupaten Ponorogo." Cendekia: Jurnal Kependidikan dan Kemasyarakatan 12(2): 211.

Mastuhu. 1988. Dinamika Sistem Pendidikan Pesantren. Jakarta: INIS.

Mohammad Hasan. 2015. "PERKEMBANGAN PENDIDIKAN PESANTREN DI INDONESIA Mohammad Hasan Pendahuluan Kajian Tentang Pesantren Sudah Banyak Dilakukan Ahli , Dengan Berbagai Perspektif - Misalnya Pendekatan Sosial Ekonomi , Politik Dan Etika Dan Tingkah Laku Ekonomi Yang Bersifat Agr." Jurnal Tadris 10(1): 56-73. https://www.researchgate.net/publication/315971324

Muhakamurrohman, Ahmad. 1970. "Pesantren: Santri, Kiai, Dan Tradisi." IBDA : Jurnal Kajian Islam dan Budaya 12(2): 109-18.

Muhammad Arifin Ismail. 2013. "Sikap Pesantren Dalam Menghadapi Paham Pluralisme Agama." Toleransi 5(Desember): 118-25.

Mujab, Saiful. 2018. "Memahami Tradisi Spiritualitas Pesantren (Sebuah Analisis Sosio-Historis Terhadap Spiritualitas Pesantren." Asketik 1(2): 79-90.

Nihwan. 2017. "Pendidikan Pesantren Dalam Mempertahankan Nilai-Nilai Pendidikan Islam." Jurnal Studi Keagamaan, Pendidikan dan Humaniora 4(1): 151-65. 
Parhan, M. \& Sutedja, B. (2019). Penerapan Pendekatan Pembelajaran Kontekstual dalam pendidikan Agama Islam di Universitas Pendidikan Indonesia. TARBAWY: Indonesian Journal of Islamic Education - Vol. 6 No. 2. 114-126.

Poerbakawatja, Soegarda. 1982. Ensiklopedia Pendidikan. Jakarta: Gunung Agung.

Shofiyyah, Nilna Azizatus, Haidir Ali, and Nurhayati Sastraatmadja. 2019. "Model Pondok Pesantren Di Era Milenial." BELAJEA: Jurnal Pendidikan Islam 4(1): 1.

Siregar, Andre Syahbana. 2018. "Sejarah Perkembangan Sistem Pendidikan Islam Di Pesantren ArRaudlatul Hasanah Kota Medan." JUSPI (Jurnal Sejarah Peradaban Islam) 2(1): 113.

Simuh. 2003. Islam dan Pergumulan Budaya Jawa. Jakarta Selatan: Teraju.

Suhardi, Didik, Direktur Pembinaan, Smp Ditjen, and Dikdas Kemdikbud. 2012. "Peran Smp Berbasis Pesantren Sebagai Upaya Penanaman Pendidikan Karakter Kepada Generasi Bangsa Boarding School-Based Smp Role As an Effort To Implement Character Education for Nation'S Successor." Pendidikan Karakter.

Suharto, Toto. 2011. "Kontribusi Pesantren Persatuan Islam Bagi Penguatan Pendidikan Islam Di Indonesia." Millah 11(1): 109-33.

Sulaiman, Rusydi. 2016. "Pendidikan Pondok Pesantren: Institusionalisasi Kelembagaan Pendidikan Pesantren." 'Anil Islam 9(1): 148-74.

Syafe'i, Imam. 2017. "PONDOK PESANTREN: Lembaga Pendidikan Pembentukan Karakter." AlTadzkiyyah: Jurnal Pendidikan Islam 8(1): 61.

Wiryosukarto, Amir Hamzah. 1996. Merintis Pesantren Modern. Ponoroogo: Gontor Press.

Zulhimma. 2013. "Dinamika Perkembangan Pondok Pesantren Di Indonesia." Jurnal Darul 'Ilmi 01(02): 166-67. 